\title{
The Educational System in Israel - Changes in Perception and Approaches since the Late 19th Century
}

\begin{abstract}
Education, by its very nature, is an institution that preserves tradition and its values, and thus preserves structures, patterns and processes that have become rooted in society and continue to influence and shape it. Education was one of the significant forces in the shaping of modern culture and the modern social cohesion of the Jewish people along with the peoples of Europe from the end of the $19^{\text {th }}$ century and throughout the entire process of its renewed hold over its land. In the period that preceded the establishment of the State the focuses of power were distributed politically, with the considerable involvement of the community in what was done in education. Since the establishment of the State, the structure of the shaping of education policy in Israel has experienced changes. The principle of statehood guided Prime Minister Ben-Gurion, who sought to apply it also to the educational system. For many years since the establishment of the State, changes have been made in the national consensus about the emphasis of values, according to the spirit of the era and the major events that occurred in the country and society in Israel. In the transition to the $21^{\text {st }}$ century, Israeli society is undergoing major changes that have direct implications on the positioning of formal education in society and on the image of the desired graduate.
\end{abstract}

Keywords: Israel, Education, Goals, Changes, Jewish people

\section{Introduction}

The educational reality in Israel, as in every society, is shaped by many factors: historical, social and cultural forces that participate in the shaping of different problems in different periods, the needs of different groups in society and the balances between them, of technological developments, social and political developments, and additional factors that participate in the process ${ }^{1}$. The educational system in Israel has experienced signifi-

${ }^{1}$ Y. Iram and R. Globeman, The Development of Teaching in the Education Institutions in Israel, Tel Aviv University, 1999. 
cant developments and many changes both prior to and since the period of the establishment of the State. This paper will present changes in the perceptions and approaches throughout history in the educational system in Israel, beginning from the end of the $19^{\text {th }}$ century.

\section{A Historical Review of the Development of the Educational System in Israel - Changes in Perception and Approaches}

Education is one of the significant forces in the formation of modern culture and the modern social cohesion of the Jewish people, along with the nations of Europe, beginning at the end of the $19^{\text {th }}$ century and throughout the period of the Jewish people's renewed hold over its land ${ }^{2}$. Education, by its very nature, is an institution that preserves tradition and values, and thus preserves the structures, patterns, and processes that are rooted in society and that continue to influence and shape it.

The Jewish national movement has used Hebrew education as a means to generate political, social, economic and cultural changes in the Jewish people. The foundations of Jewish education (drawing from three sources: traditional Jewish education, modern schools in the spirit of the Jewish enlightenment movement, and the Jewish national movement that established Jewish educational institutions) began to develop from the end of the $19^{\text {th }}$ century and bore fruit in the first half of the $20^{\text {th }}$ century ${ }^{3}$. When Hebrew became the exclusive language of schooling, teachers became the propagators of nationality, and its contents, symbols and messages were channelled and internalised as a source of identification of the students with the idea of the Jewish people ${ }^{4}$. The infrastructure that was created served as a basis for the educational system of the State of Israel ${ }^{5}$.

In the period of the Yishuv (the community of Jewish residents in Israel before the establishment of the State) the political framework in which education operated was voluntary. The educational system operated outside of a binding political framework and without laws of education. In the 1850s there began processes of modernisation in education in the land of Israel. Jewish donors established educational institutions in Israel as a part of programmes to promote the productivity of the Jewish community. Although traditional education remained the dominant and most widespread model according to

\footnotetext{
${ }^{2}$ Y. Shelhav, The Changes in the Jewish Educational System in the Land of Israel in the Years 1933-1939. M.A. Thesis. Ramat Gan: Bar Ilan University, 1972.

${ }^{3}$ R. Alboim Dror, The Roots of the Educational System in Israel, in: Jubilee of the Educational System in Israel, ed. by E. Peled, Vol. 1, Ministry of Education and Culture, 1986.

${ }^{4}$ Y. Keshti, Toward Multicultural Education in Israel, "Two Thousand: Interdisciplinary Journal for Review of Philosophy and Literature" 34, 2009, 261-280.

${ }^{5}$ R. Alboim Dror, op. cit., passim.
} 
which most of the children learned, it was no longer the sole model when the Zionist movement began to open educational institutions towards the end of the $19^{\text {th }}$ century ${ }^{6}$.

The establishment of the Teachers Union at the beginning of the $20^{\text {th }}$ century (1913) changed the patterns of control in education and became a professional factor of authority that created the infrastructure for national education. In the 1920s, changes occurred in the status of the Teachers Union with regard to the organisations that set educational policy, of which the most prominent ones are the political parties ${ }^{7}$. The foci of power were politically decentralised, with considerable involvement of the community in what was done in education ${ }^{8}$.

The sector method (involving the general sector, the workers sector, and the Mizrachi sector) was the most significant expression of the involvement of political factors in the different educational organisations ${ }^{9}$. Every sector had considerable influence in the setting of policy, primarily due to the political, ideological, and financial resources at their disposal ${ }^{10}$. Despite the differences in ideological background and in the approach to education of each one of these sectors, they held shared values that belonged to the educational system in the period of the Yishuv which addressed the renewal of the Jewish people in its country, the establishment of the State of Israel, and the fulfilment of the Zionist vision. This loyalty to the idea of the national revival and the connection to the main institutions created a pedagogical national common denominator for all three sectors $^{11}$.

The shared infrastructure of values and the education for tolerance in the period of the Yishuv was therefore one of the main characteristics of the educational system in the different sectors. This was out of respect for human dignity and the dignity of the people, and out of the maintenance of the right of all the sectors to live, to grow, and to develop according to their conscience, with the fulfilment of the unification of the people in the period of the "state on the way" 12 .

Since the establishment of the State of Israel, the educational system in Israel has coped with the aspiration to provide education for all in the spirit of the civil equality of

6 The Yishuv refers to the civilian society in the land of Israel that preceded the establishment of the State and laid the infrastructure for both the society and citizenship. It founded factories, built residential communities, provided welfare services and created a new culture. The most prominent trait of civil society in the period of the Yishuv was adherence to national tasks. Groups and organisations acted in the shadow of the flag and responded to a call to serve that did not come from a sovereign source of authority, but from a belief in the goal and the sense of a shared fate. See: Y. Yishai, Between Recruitment and Pacification, Civil Society in Israel. Carmel Press. 2003.

7 R. Alboim Dror, op. cit., passim.

${ }^{8}$ H. Gaziel, The Policy of Education in Israel: Structures and Processes, in: Jubilee of the Educational System in Israel, ed. by E. Peled. Vol. 1, Ministry of Education and Culture, 1999.

9 Y. Keshti, Education as Identity and Action, Tel Aviv: Hidekel Ltd., 2013.

${ }^{10}$ H. Gaziel, op. cit., passim

${ }^{11}$ Echad Ha'am. The Rebirth of the Spirit, in: idem, This Is Not the Way, HaMelitz, 1889.

${ }_{12}$ M. Shechter and Y. Iram. Fifty Years of Education for Values - From an Emerging Society to a Changing Society - A Developmental Review, in: Values and Education in Israeli Society, ed. by Y. Iram, S. Shkolnikov, Y. Cohen, and A. Shechter, Jerusalem 2001. 
the Declaration of Independence (1948), against the background of the especially great difference and broad gaps in the population of students. The perception of the difference between students and of the way to cope with this has experienced decisive changes from the establishment of the country until today. These changes reflect the social changes that society in Israel has experienced since its foundation and is still experiencing today ${ }^{13}$.

With the establishment of the country, the State of Israel inherited a developed educational system that immediately functioned fully and absorbed tens of thousands of immigrant children. However, the new state also inherited a system that was divided and split in organisational and ideological terms, whose different components, under the auspices of the parties and the local government, competed and struggled against one another and eroded the authority of the educational system to the point that it harmed its ability to function. Mass immigration during the first years of the country's existence and the tremendous and rapid growth in the population and complexity of the educational system caused an acceleration of the processes of bureaucratisation, division, and formalisation of the system. The need to build a country under conditions of siege and struggle, and to absorb hundreds of thousands of immigrants from different cultures within a short period of time, created the need for the unification of all the education system's different components and the concentration of all forces in a national project ${ }^{14}$.

The educational system shifted from the authority of the 'National Council' to the authority of the State, and the Ministry of Education and Culture was established. About half a year later, the Knesset (Israeli Parliament) passed the Compulsory Education Law, 1949. In this law, the State decided to democratise elementary education ${ }^{15}$ and make it a service offered for all ${ }^{16}$.

The principle of statehood was the guiding light of the then Prime Minster, Ben-Gurion, and he sought to apply it to the educational system. The practical significance of the implementation of statehood as the leading motif in educational policy was administrative centralisation through the centralisation of the foci of power in the government leadership $^{17}$.

In 1954 the State Education Law was enacted, determining the "aspiration to the intellectual and cultural equality of all children of Israel"18. The then Minister of Education, Ben_Zion Dinur, phrased it nicely: uniformity in the inputs for students (in terms of money, personnel, content and methods) without taking into account different needs, uniformity of supervision, uniformity of curricula and teaching methods, and a hierarchi-

${ }^{13}$ H. Aplboim, E. Gotterman, and A. Brikner, Individualized Instruction: Its Elements and Historical and Educational Sources, Unit 2, The Open University, 1989.

14 R. Alboim Dror, op. cit..

15 According to the Compulsory Education Law, 1949, elementary school education refers to the instruction provided in the course of nine school years and generally designed for children of the ages from 5 to 13 years inclusive, such school years including one school year of kindergarten education and eight school years in classes I to VIII inclusive.

${ }^{16}$ H. Aplboim, E. Gotterman, and A. Brikner, op. cit.

17 H. Gaziel, op. cit.

${ }^{18}$ H. Aplboim, E. Gotterman, and A. Brikner, op. cit. 
cal organisational structure, and all this for the purpose of the melting pot and formal equality ${ }^{19}$.

The State Education Law $^{20}$ emphasises the national element in education. The law included 13 goals intended to shape the directions of education for young people in the State of Israel. In 1979, an amendment was introduced to the law through the addition of the $14^{\text {th }}$ goal, which pertains to the awareness of the memory of the Holocaust and acts of bravery ${ }^{21}$.

At the base of the conception of the educational system is the assumption that it is possible to grant equality of opportunities for all students by providing equal amounts of education for all students ${ }^{22}$.

The price of the success of the educational system in its tasks following the establishment of the State was the subordination of the objectives of the different groups and subcultures to the national supra-objective, while ignoring the needs of the individual ${ }^{23}$. At the end of the 1950s, it became clear that the rate of dropping out from elementary school had increased, and the gaps between students remained.

The complex social reality and the criticism of researchers and educators forced the educational system to change the manner of care of weaker groups. The necessity of creating distinct curricula, methods, and frameworks which suited the needs of the different students, began to be recognised ${ }^{24}$. The policy of cultivation of the 1960 s sought to reduce the differences in the diverse population of students through an attempt to adjust the different processes and means of teaching to suit weaker populations, with the hope that the diversification of those means would lead to more equal achievement of these goals among all students.

The educational system did not fundamentally change its educational objectives. The objective - to reduce differences - remained. This objective reflected a social perception that addresses social equality in terms of uniformity ${ }^{25}$. Following the introduction of the policy of cultivation in the 1960s, real results were not seen in the reduction of the gaps in learning achievements, and thus the feeling grew that as long as the composition of the students is homogenous in cultural, social and economic terms there is no chance to improve the achievements of disadvantaged students. From this point onwards, the educational system adopted an approach that sees the heterogeneous composition of the class and the school to be the basis for equal policy in the field of achievements. The realisa-

\footnotetext{
${ }^{19}$ H. Gaziel, op. cit., passim.

${ }^{20}$ According to the State Education Law, 1953, state education means education that is given by the State according to the curriculum determined according to law, regardless of connection to party, ethnic or any organisational factor outside of the government.

${ }^{21}$ Y. Shelhav, op. cit.

${ }^{22}$ H. Aplboim, E. Gotterman, and A. Brikner, op. cit.

${ }^{23}$ R. Alboim Dror, op. cit., passim.

${ }^{24}$ H. Aplboim, E. Gotterman, and A. Brikner, op. cit.

25 Ibidem.
} 
tion of integration encountered many difficulties. Homogenous groups were created in classes, which increased the gaps in achievements and in social terms ${ }^{26}$.

In the 1970s there began to appear new trends in Israeli society, and in the educational system: the recognition increased that in a pluralistic democratic society 'equality' means recognition of the right of people to be different. In the educational system there is a tendency towards greater individualisation in teaching. The term 'equality of opportunities' assumes a different significance: instead of the aspiration to reduce the difference, there is increasing recognition of the need to respect differences. The process of education attempts to grant equal opportunities through giving different amounts to each person according to his ability and needs. The educational system does not ignore social goals; it just defines them differently ${ }^{27}$.

In the transition to the $21^{\text {st }}$ century, Israeli society is undergoing major changes that have direct implications on the position of formal education in society and the figure of the desired adult graduate. While the first forty years of the State were marked by the very establishment of the country and its defence as the primary national priority, in the $21^{\text {st }}$ century Israeli society attributes priority to the individual and his status ${ }^{28}$. The educational system is committed to the merger between education and the inculcation of Jewish cultural assets in the spirit of democracy and value-oriented education that cultivates the values and instruments of value-based choice on the level of the individual. The balance between particularistic values and universal values is made possible, on the one hand, through the exposure of the richness of traditions and value-oriented approaches in Jewish culture and, on the other hand, through the value that the democratic perception gives to the right and ability of each person to live and cultivate the values of their specific culture ${ }^{29}$.

This article has presented the changes and developments that occurred and are still occurring in the educational system in Israel, from the end of the 19th century and before the establishment of the State. This is an education that preserves the tradition and values of Jewish society and, in general, is shaped by many factors and major events that have been experienced by the State and society in Israel: historical, national, value-oriented, political, social, needs of the hour, diverse developments, and so on. These factors constitute a significant and integral part of the development of the educational system in Israel.

26 Ibidem.

27 Ibidem.

${ }_{28}$ M. Shechter and Y. Iram, op. cit.

29 D. Gordon, All Together and Each Separately: Themes to the Image of Another Educational System, Jerusalem: Ministry of Education, Culture, and Sport, 1995. 


\section{References}

Alboim-Dror, R., The Roots of the Educational System in Israel, in: Jubilee of the Educational System in Israel, edited by E. Peled, Vol. 1, Ministry of Education and Culture, 1986.

Aplboim, H., E. Gotterman, and A. Brikner. Individualized Instruction: Its Elements and Historical and Educational Sources, Unit 2, The Open University, 1989.

Echad Ha'am. The Rebirth of the Spirit, in: idem, This Is Not the Way, HaMelitz, 1889.

Gaziel, H., The Policy of Education in Israel: Structures and Processes, in: Jubilee of the Educational System in Israel, edited by E. Peled. Vol. 1, Ministry of Education and Culture, 1999.

Gordon, D. All Together and Each Separately: Themes to the Image of Another Educational System. Jerusalem: Ministry of Education, Culture, and Sport, 1995.

Iram, Y., and R. Globeman. The Development of Teaching in the Education Institutions in Israel. Tel Aviv University, 1999.

Keshti, Y., Toward Multicultural Education in Israel, "Two Thousand: Interdisciplinary Journal for Review of Philosophy and Literature" 34, 2009, p. 261-280.

Keshti, Y. Education as Identity and Action, Tel Aviv: Hidekel Ltd., 2013.

Shechter, M., and Y. Iram, Fifty Years of Education for Values - From an Emerging Society to a Changing Society - A Developmental Review, in: Values and Education in Israeli Society, ed. by Y. Iram, S. Shkolnikov, Y. Cohen, and A. Shechter, Jerusalem 2001.

Shelhav, Y. The Changes in the Jewish Educational System in the Land of Israel in the Years 1933-1939. M.A. Thesis. Ramat Gan: Bar Ilan University 1972.

Yishai, Y. Between Recruitment and Pacification, Civil Society in Israel, Carmel Press. 2003. 
